\title{
PENGARUH NIKOTIN TERHADAP KELAINAN TULANG DAN ORGAN INTERNAL MENCIT (Mus musculus)
}

\author{
Pieter Kakisina*, Win Darmanto*), Bambang Poernomo**) \\ *Jurusan Biologi FMIPA UNPATTI, *) Jurusan Biologi FMIPA UNAIR, \\ ${ }^{\star *}$ ) Fakultas Kedokteran Kedokteran UNAIR
}

\begin{abstract}
This study was designed to identify the effects of nicotine on the skeletal and internal organ abnormalities of mice prenatally. Seventy two female mice strain Balb/C were used. Pregnant mice on gestation days (GD) 8, 10, and 12 was injected intraperitoneally with 3, 6, and $12 \mathrm{mg} / \mathrm{kg}$ BW nicotine respectively. Control nice was injected by aguabidestylata. On GD 18, and all of pregnant mice were sacrificed, and a half of living fetuses were immersed in Bouin's solution to observe their internal organs, while another half were immersed in 95\% ethanol to observed sekeletal malformation using alizarin red S staining. Results were analyzed using SPSS program version 11 for personal computer.

The results showed that nicotine caused Skeletal malformation, especially in the sternum when administered on GD 8 and 10, in doses of 3 and $6 \mathrm{mg} / \mathrm{kg} \mathrm{BW}$, delayed of ossification was observed in the supraoccipital and sacrocaudal bones on GD 10 and 12 and doses of $12 \mathrm{mg} / \mathrm{kg} \mathrm{BW}$, while in the extremitas the malformation was observed in the proximal and medial phalanx both in the fore and hind limb especially on GD 10 and 12, and doses of 6 and $12 \mathrm{mg} / \mathrm{kg} \mathrm{BW.} \mathrm{Nicotine} \mathrm{was} \mathrm{effects} \mathrm{on} \mathrm{the} \mathrm{brain} \mathrm{development} \mathrm{especially}$ hydrocephalus was observed on GD 8 and doses 10 and $12 \mathrm{mg} / \mathrm{kg} \mathrm{BW}$. Another internal malformation such as ectopic renalis was observed on GD 8 and doses of 3 and $6 \mathrm{mg} / \mathrm{kg} B W$. These finding suggested that nicotine has caused skeletal malformation, brain malformatin and ectopic renalis, when administered in mice prenatally.
\end{abstract}

Key words: ectopic renalis, hydrocephalus, mice, nicotine, skeletal malformation

\section{PENGANTAR}

Nikotin merupakan salah satu komponen dalam asap rokok yang diperkirakan menjadi penyebab dari kebiasaan merokok (Britton et al., 2001). Nikotin dalam dosis rendah menyebabkan eksitasi yang dirasakan sebagai kenikmatan tetapi pada dosis yang tinggi menyebabkan inhibisi setelah eksitasi sepintas, yang mendorong perokok ingin terus merokok (Comroe, 1960; Amitage et al., 1975; Benowittz, 1980).

Setiap tahun di seluruh dunia terdapat 3 juta kematian akibat penyakit yang dihubungkan dengan rokok dan diduga dapat meningkat sampai lebih dari 10 juta kematian per tahun. Kematian akibat kanker paru pada wanita saat ini telah melebihi jumlah kematian akibat kanker payudara. Hal tersebut diakibatkan peningkatan jumlah wanita yang merokok setiap tahun (Aniwidyaningsih, 2003).

Pengaruh langsung rokok pada ibu hamil adalah sebagai akibat nikotin yang terkandung di dalamnya. Nikotin ini menimbulkan vasokontriksi pada pembuluh darah, akibatnya aliran darah ke janin melalui tali pusar janin akan berkurang sehingga mengurangi kemampuan distribusi zat makanan yang diperlukan oleh janin. Nikotin diketahui juga mengganggu absorpsi kalsium, vitamin C, dan vitamin lain serta mineral yang diperlukan untuk pertumbuhan fetus (Elliot dan Unger, 2000).
Wanita yang merokok pada masa kehamilan dapat menyebabkan gangguan pada kemampuan reproduksinya berupa penurunan pertumbuhan intrauterus fetus, abortus, kelahiran prematur, resiko terjadinya mortalitas prenatal, dan neonatal, serta menyebabkan malformasi pada fetus (Werler et al., 1985). Merokok pasif selama kehamilan dapat mengakibatkan anomali jaringan dan kelainan perubahan biokimia pada anak (Anonim, 2003).

Tujuan dari penelitian ini adalah untuk mengetahui pengaruh nikotin terhadap munculnya kelainan rangka dan kelainan organ internal fetus mencit yang diberikan pada masa prenatal.

\section{BAHAN DAN CARA KERJA}

Rancangan yang digunakan dalam penelitian ini adalah Rancangan Acak Langkap (RAL) pola faktorial $3 \times 4$ dengan ulangan/replikasi sebanyak 6 (enam) kali.

Pelaksanan penelitian ini berlangsung pada bulan juni sampai dengan bulan Agustus 2003. Pemeliharaan hewan coba mencit dilakukan di Laboratorium Fisiologi Reproduksi Fakultas Kedokteran Hewan Universitas Airlangga. Pemeriksaan bentuk-bentuk kecacatan fetus mencit dilakukan di Laboratorium Embriologi Fakultas Kedokteran Hewan Universitas Airlangga Surabaya. 
Hewan percobaan yang digunakan adalah 120 mencit betina dara galur $\mathrm{BALB} / \mathrm{C}$, umur 8-10 minggu dengan berat 20-35 g dan 40 mencit jantan umur lebih dari 8 minggu. Mencit dibagi dalam 3 kelompok berdasarkan umur kebuntingan (UK) 8, 10, dan 12 hari, setiap kelompok diberi nikotin 3, 6, dan 12 mg/kgBB, sedangkan kelompok kontrol diberi aquabidestilata.

Dosis yang digunakan pada penelitian ini ditentukan berdasarkan uji pendahuluan $\mathrm{LD}_{50}$ secara intraperitoneal adalah sebesar $24 \mathrm{mg} / \mathrm{kg}$ BB. Berdasarkan $\mathrm{LD}_{50}$ ditentukan dosis tertinggi di bawah $\mathrm{LD}_{50}$ yang tidak menyebabkan kematian pada induk ditambah dua dosis di bawahnya (1/2, 1/4, dan $1 / 8$ dari $\mathrm{LD}_{50}$ ), yaitu sebesar 12 , 6 , dan $3 \mathrm{mg} / \mathrm{kg}$ BB yang berasal dari nikotin cair dengan kemurnian 97\% dilarutkan dalam aquabidestilata.

Pada UK 18 hari, induk mencit dikorbankan untuk dibedah, fetus hidup dimasukkan ke dalam $\mathrm{NaCl}$ 0,9\%. Setengah dari jumlah fetus hidup difiksasi dalam larutan Boiun's untuk pengamatan kelainan internal meliputi otak (serebrum) dan ginjal. Sisa fetus hidup difiksasi dengan alkohol 96\% untuk selanjutnya dilakukan pewarnaan rangka dengan menggunakan alizarin's red S 0,01\%.

Data hasil penelitian yaitu: jumlah komponen rangka aksial dan rangka anggota yang sudah menulang, persentase kejadian kelainan rangka dari semua kelompok perlakuan dianalisis dengan menggunakan analisis ANOVA dan dilanjutkan dengan uji BNT.

\section{HASIL}

Pengamatan kelambatan penulangan pada tulang supraoksipital fetus terjadi pada dosis nikotin 6 dan $12 \mathrm{mg} / \mathrm{kg}$ BB pada UK 8 hari, sedangkan UK 10 hari kelambatan tersebut terjadi pada dosis nikotin $12 \mathrm{mg} / \mathrm{kg}$ BB. UK 12 hari kelambatan penulangan tulang supraoksipital terjadi pada semua dosis dan meningkat seiring dengan peningkatan dosis nikotin yang diberikan. Hasil tersebut dapat dilihat pada Tabel 1 dan Gambar 1.

Tabel 1. Persentase kelambatan penulangan pada tulang supraoksipital fetus setelah pemberian berbagai dosis nikotin pada induk dengan umur kebuntingan tententu

\begin{tabular}{cccccr}
\hline \multirow{2}{*}{$\begin{array}{c}\text { Umur } \\
\text { Kebuntingan } \\
\text { (hari) }\end{array}$} & \multicolumn{4}{c}{ Dosis Nikotin (mg/kg BB) } & Rerata \\
\cline { 2 - 5 } & $\mathbf{0}$ & $\mathbf{3}$ & $\mathbf{6}$ & $\mathbf{1 2}$ & \\
\hline 8 & 0.00 & 0.00 & 16.67 & 29.17 & 11.46 \\
10 & 0.00 & 0.00 & 0.00 & 29.17 & 7.61 \\
12 & 0.00 & 20.83 & 10.09 & 12.49 & 10.88 \\
\hline Rerata & $0.00^{\text {a }}$ & $7.35^{\text {a }}$ & $8.85^{\text {a }}$ & $23.61^{\text {b }}$ & 10.00 \\
\hline
\end{tabular}

Keterangan: superskrip huruf yang sama tidak berbeda nyata $(p>0,05)$

Dari hasil uji BNT, pemberian nikotin dosis $12 \mathrm{mg} / \mathrm{kg}$ $\mathrm{BB}$, menunjukkan adanya perbedaan yang nyata bila dibandingkan dengan kontrol terhadap persentase kelambatan penulangan tulang supraoksipital fetus pada $\alpha=0,05$. Sedangkan dosis nikotin 0,3 , dan $6 \mathrm{mg} / \mathrm{kg}$ BB
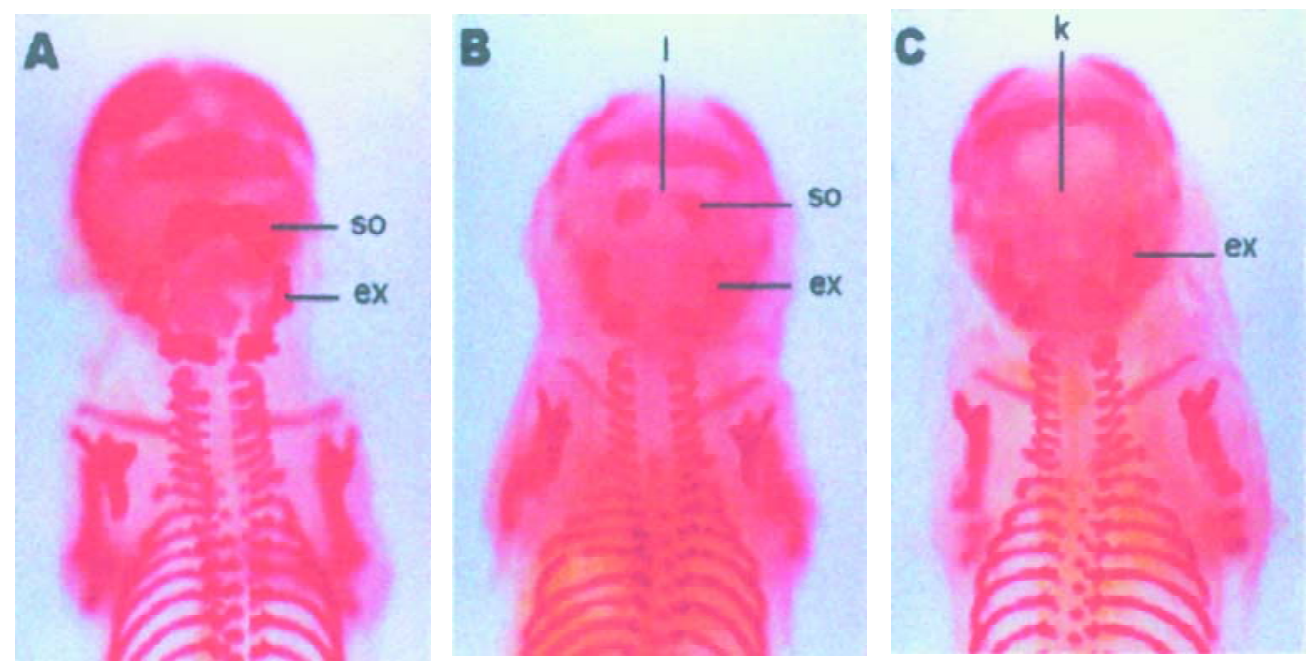

Gambar 1. Kelambatan Penulangan Tulang Supraoksipital pada Fetus Mencit (perbesaran $8 \times$ ) $\mathrm{A}=$ Kontrol; B, C = Perlakuan; so = supraoksipital ex = eksoksipital; I = kelambatan penulangan tulang supraoksipital; $\mathrm{k}=$ tidak terbentuk tulang supraoksipital 
tidak menunjukkan adanya perbedaan yang nyata terhadap persentase kelambatan penulangan tulang supraoksipital fetus pada $\alpha=0,05$.

Kelambatan penulangan tulang sakrokaudalis menurun seiring dengan peningkatan dosis pada semua umur kebuntingan. Sedangkan UK 12 hari dengan dosis nikotin $12 \mathrm{mg} / \mathrm{kg}$ BB fetus belum mengalami penulangan. Hasil tersebut dapat dilihat pada Tabel 2 dan Gambar 2.

Tabel 2. Jumlah tulang sakrokaudalis fetus setelah pemberian berbagai dosis nikotin pada induk dengan umur kebuntingan tertentu

\begin{tabular}{|c|c|c|c|c|c|}
\hline \multirow{2}{*}{$\begin{array}{c}\text { Umur } \\
\text { Kebuntingan } \\
\text { (hari) }\end{array}$} & \multicolumn{4}{|c|}{ Dosis Nikotin (mg/kg BB) } & \multirow[b]{2}{*}{ Rerata } \\
\hline & 0 & 3 & 6 & 12 & \\
\hline 8 & 12.17 & 7.92 & 5.48 & 3.09 & $7.16^{k}$ \\
\hline 10 & 12.33 & 7.37 & 5.14 & 1.67 & $6.63^{\prime}$ \\
\hline 12 & 12.33 & 2.25 & 1.13 & 0.00 & $3.93^{m}$ \\
\hline Rerata & $12.28^{a}$ & $5.84^{b}$ & $3.91^{c}$ & $1.58^{d}$ & 5.91 \\
\hline
\end{tabular}

Keterangan: superskrip huruf yang sama tidak berbeda nyata $(p>0,05)$

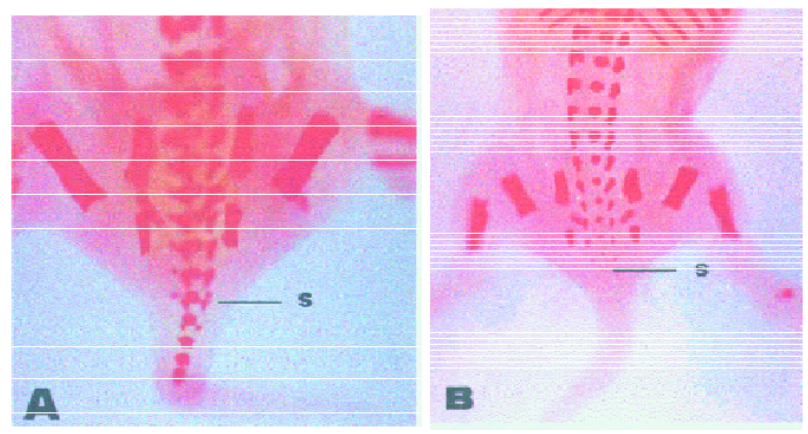

Gambar 2. Kelambatan Penulangan Tulang Sakrokaudalis (perbesaran $8 \times$ )

$\mathrm{A}=$ Kontrol; $\mathrm{B}=$ Perlakuan; $\mathrm{s}=$ sakrokaudalis

Dari hasil uji BNT, terlihat bahwa UK 8, 10, dan 12 hari menunjukkan perbedaan yang nyata terhadap persentase kelambatan penulangan tulang sakrokaudalis pada $\alpha=0,05$.

Pemberian nikotin dosis 0, 3, 6, dan $12 \mathrm{mg} / \mathrm{kg}$ BB, menunjukkan adanya perbedaan yang nyata bila dibandingkan kontrol terhadap persentase kelambatan penulangan tulang sakrokaudalis fetus pada $\alpha=0,05$.

Pengamatan terhadap rangka anggota meliputi rata-rata jumlah tulang metapodium dan tulang phalanx untuk rangka anggota depan, rata-rata jumlah tulang mesopodium, dan tulang phalanx untuk rangka anggota belakang.

Penulangan tulang phalanx anggota depan fetus terjadi penurunan seiring dengan peningkatan dosis nikotin yang digunakan pada semua umur kebuntingan. Hasil tersebut dapat dilihat dengan jelas pada Tabel 3 dan Gambar 3.
Tabel 3. Rata-rata jumlah tulang phalanx proksimal ditambah median anggota depan fetus setelah pemberian berbagai dosis nikotin pada induk dengan umur kebuntingan tertentu

\begin{tabular}{|c|c|c|c|c|c|}
\hline \multirow{2}{*}{$\begin{array}{c}\text { Umur } \\
\text { Kebuntingan } \\
\text { (hari) }\end{array}$} & \multicolumn{4}{|c|}{ Dosis Nikotin (mg/kg BB) } & \multirow[b]{2}{*}{ Rerate } \\
\hline & 0 & 3 & 6 & 12 & \\
\hline 8 & 8.00 & 6.67 & 5.02 & 2.38 & $5.52^{k}$ \\
\hline 10 & 8.00 & 6.17 & 5.67 & 1.32 & $8.29^{k}$ \\
\hline 12 & 7.83 & 1.33 & 1.00 & 0.00 & $2.54^{\prime}$ \\
\hline Rerata & $7.94^{a}$ & $4.72^{\text {be }}$ & 3.89 cef & $1.23^{d f}$ & 5.45 \\
\hline
\end{tabular}

Keterangan: superskrip huruf yang sama tidak berbeda nyata $(p>0,05)$

Dari hasil uji BNT terlihat bahwa UK 8 hari dibandingkan dengan UK 12 hari dan UK 10 hari dengan UK 12 hari menunjukkan perbedaan yang nyata terhadap jumlah tulang phalanx proksimal ditambah phalanx median anggota depan fetus pada $\alpha=0,05$. Sedangkan UK 8 hari dengan UK 10 hari menunjukkan perbedaan yang tidak nyata terhadap jumlah tulang phalanx proksimal ditambah phalanx median anggota depan fetus pada $\alpha=0,05$.

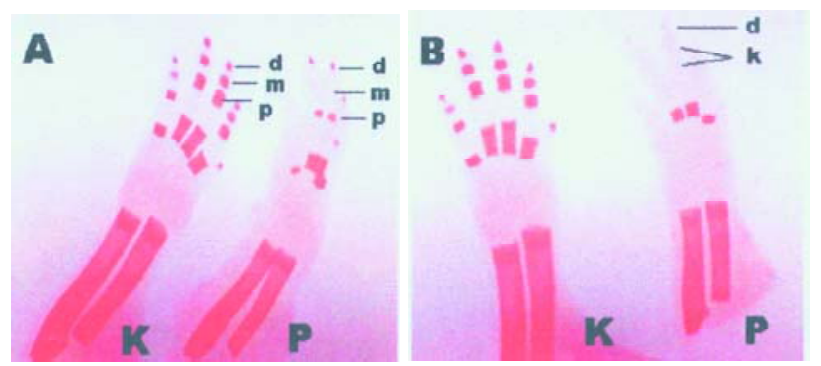

Gambar 3. Kelambatan Penulangan Tulang Phalanx Anggota Depan Fetus Mencit (perbesaran $12 \times$ )

$\mathrm{A}=$ Umur 10 hari; $\mathrm{B}=$ Umur 12 hari; $\mathrm{K}=$ Kontrol; $\mathrm{P}=$ Perlakuan; $\mathrm{p}=$ proksimal $; \mathrm{m}=$ median; $\mathrm{d}=$ distal $; \mathrm{k}=$ kelambatan penulangan

Pemberian nikotin dosis $0 \mathrm{mg} / \mathrm{kg}$ BB dengan 3, 6, dan $12 \mathrm{mg} / \mathrm{kg} \mathrm{BB}, 3 \mathrm{mg} / \mathrm{kg}$ BB dengan $12 \mathrm{mg} / \mathrm{kg}$ BB menunjukkan adanya perbedaan yang nyata terhadap jumlah tulang phalanx proksimal ditambah phalanx median anggota depan fetus pada $\alpha=0,05$. Sedangkan pemberian dosis nikotin $3 \mathrm{mg} / \mathrm{kg}$ BB dengan $6 \mathrm{mg} / \mathrm{kg}$ dan $6 \mathrm{mg} / \mathrm{kg}$ BB dengan $12 \mathrm{mg} / \mathrm{kg}$ BB tidak menunjukkan perbedaan yang nyata terhadap jumlah tulang phalanx proksimal ditambah phalanx median anggota depan fetus pada $\alpha=0,05$.

Penulangan tulang phalanx proksimal ditambah median anggota belakang fetus juga terjadi penurunan seiring dengan peningkatan dosis nikotin yang digunakan pada semua umur kebuntingan induk. Pemberian nikotin dosis 
$12 \mathrm{mg} / \mathrm{kg}$ BB pada induk dengan UK 12 hari tidak dapat teramati sebab pola pembentukan anggota pada Uk 12 hari sudah sudah terbentuk dari pada UK sebelumnya yaitu UK 8 dan 10 hari, sehingga UK 12 lebih resisten daripada UK 8 atau 10 (Darmanto, 1993). Hasil tersebut dapat dilihat dengan jelas pada Tabel 4 dan Gambar 4.

Tabel 4. Rata-rata jumlah tulang phalanx proksimal ditambah median anggota belakang fetus setelah pemberian berbagai dosis nikotin pada induk dengan umur kebuntingan tertentu

\begin{tabular}{|c|c|c|c|c|c|}
\hline \multirow{2}{*}{$\begin{array}{c}\text { Umur } \\
\text { Kebuntingan } \\
\text { (hari) }\end{array}$} & \multicolumn{4}{|c|}{ Dosis Nikotin (mg/kg BB) } & \multirow[b]{2}{*}{ Rerata } \\
\hline & 0 & 3 & 6 & 12 & \\
\hline 8 & 8.67 & 7.50 & 5.83 & 2.46 & 6.11 \\
\hline 10 & 9.00 & 6.53 & 5.22 & 1.33 & 5.52 \\
\hline 12 & 8.67 & 1.33 & 0.67 & 0.00 & 2.67 \\
\hline Rerata & $8.78^{a}$ & $5.12^{\text {be }}$ & 3.91 cef & $1.26^{\mathrm{df}}$ & 4.77 \\
\hline
\end{tabular}

Keterangan: superskrip huruf yang sama tidak berbeda nyata $(p>0,05)$
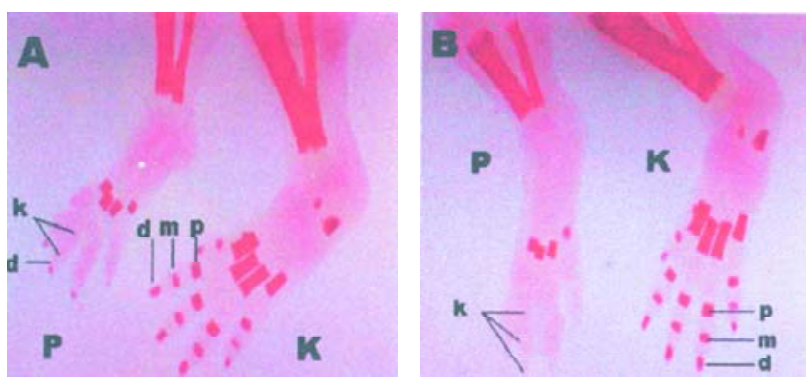

Gambar 4. Kelambatan Penulangan Tulang Phalanx Anggota Belakang Fetus Mencit. (perbesaran $12 \times$ ).

$\mathrm{A}=$ Umur 10 hari; $\mathrm{B}=$ Umur 12 hari; $\mathrm{K}=$ kontrol; $\mathrm{P}=$ perlakuan; $\mathrm{p}=$ proksimal $; \mathrm{m}=$ median; $\mathrm{d}=$ distal; $\mathrm{k}=$ kelambatan penulangan

Dari hasil uji BNT, terlihat bahwa umur kebuntingan hari ke-8 dengan hari ke-12 dan hari ke-10 dengan hari ke-12 menunjukkan perbedaan yang nyata terhadap jumlah tulang phalanx proksimal ditambah phalanx median anggota belakang fetus pada $\alpha=0,05$. Sedangkan hari ke8 dengan hari ke-10 menunjukkan perbedaan yang tidak nyata terhadap jumlah tulang phalanx proksimal ditambah phalanx median anggota belakang fetus pada $\alpha=0,05$.

Pemberian nikotin dosis 3, 6, dan $12 \mathrm{mg} / \mathrm{kg}$ BB dengan kontrol, 3 mg/kg BB dengan 12 mg/kg BB menunjukkan adanya perbedaan yang nyata (berbeda nyata) terhadap jumlah tulang phalanx proksimal ditambah phalanx median anggota belakang fetus pada $\alpha=0,05$. Sedangkan pemberian dosis nikotin $3 \mathrm{mg} / \mathrm{kg}$ BB dengan $6 \mathrm{mg} / \mathrm{kg}$ dan $6 \mathrm{mg} / \mathrm{kg}$ BB dengan $12 \mathrm{mg} / \mathrm{kg}$ BB menunjukkan perbedaan yang tidak nyata terhadap jumlah tulang phalanx proksimal ditambah phalanx median anggota belakang fetus pada $\alpha=0,05$.

Persentase kejadian sternebra terjadi peningkatan seiring dengan peningkatan dosis yaitu 6 dan $12 \mathrm{mg} / \mathrm{kg} \mathrm{BB}$, pada UK 8 hari dan pada UK 10 hari dengan dosis $12 \mathrm{mg} / \mathrm{kg}$ BB. Sedangkan pada UK 12 hari terjadi seiring dengan peningkatan dosis 3 dan $6 \mathrm{mg} / \mathrm{kg}$ BB. Hasil tersebut dapat dilihat dengan jelas pada Tabel 5 dan Gambar 5.

Tabel 5. Persentase kejadian sternebra fetus setelah pemberian berbagai dosis nikotin pada induk dengan umur kebuntingan tertentu

\begin{tabular}{cccccc}
\hline $\begin{array}{c}\text { Umur } \\
\text { Kebuntingan } \\
\text { (hari) }\end{array}$ & $\mathbf{0}$ & $\mathbf{3}$ & $\mathbf{6}$ & $\mathbf{1 2}$ & Rerata \\
\cline { 2 - 5 } & 0.00 & 0.00 & 16.67 & 29.17 & 11.46 \\
8 & 0.00 & 0.00 & 0.00 & 29.17 & 7.29 \\
10 & 0.00 & 8.33 & 20.83 & 0.00 & 7.29 \\
12 & $0.00^{\mathrm{a}}$ & 2.78 a & 12.50 ac & $19.44 \mathrm{bc}$ & 8.68 \\
\hline Rerata &
\end{tabular}

Keterangan: superskrip huruf yang sama tidak berbeda nyata $(p>0,05)$

Secara umum dapat diungkapkan bahwa pengamatan terhadap rangka menunjukkan adanya efek nikotin pada proses penulangan berupa kelambatan yaitu pada dosis nikotin 3, 6, dan $12 \mathrm{mg} / \mathrm{kg}$ BB pada UK 10 dan 12 hari, sehingga dapat disimpulkan bahwa nikotin lebih bersifat menghambat perkembangan embrio khususnya proses osifikasi daripada menyebabkan kelainan.

Dari hasil uji BNT, terlihat bahwa pemberian nikotin dosis $12 \mathrm{mg} / \mathrm{kg}$ BB dengan kontrol dan dosis $3 \mathrm{mg} / \mathrm{kg}$ BB dengan $12 \mathrm{mg} / \mathrm{kg}$ BB menunjukkan adanya perbedaan yang nyata terhadap jumlah persentase kejadian kelainan sternebra fetus pada $\alpha=0,05$. Sedangkan pemberian nikotin dosis 3 dan $6 \mathrm{mg} / \mathrm{kg}$ dibandingkan dengan kontrol dan $6 \mathrm{mg} / \mathrm{kg}$ BB dengan $12 \mathrm{mg} / \mathrm{kg}$ BB tidak menunjukkan perbedaan yang nyata terhadap jumlah persentase kejadian kelainan sternebra fetus pada $\alpha=0,05$. 

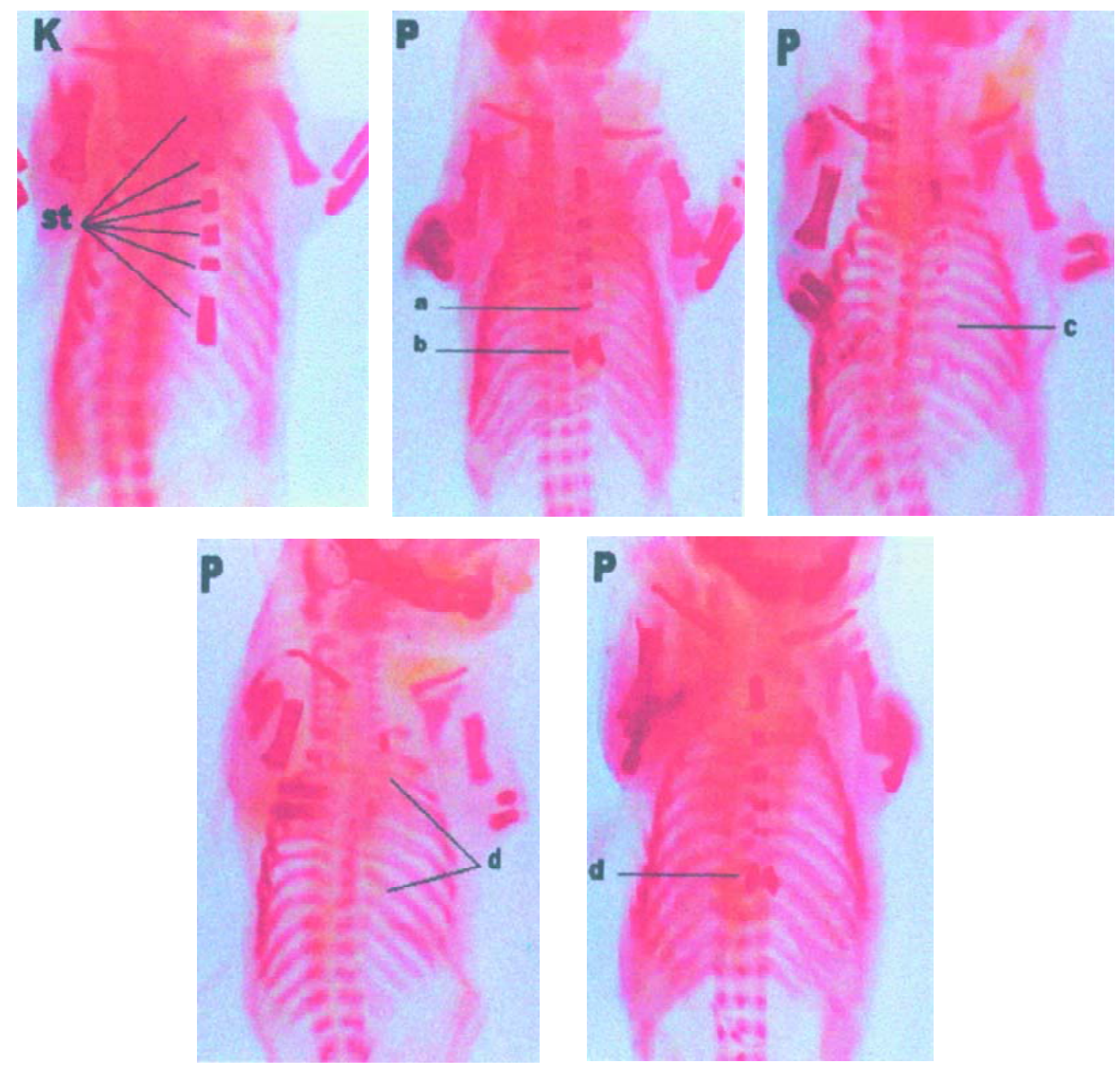

Gambar 5. Kejadian Kelainan Perkembangan Tulang Sternum (perbesaran $10 \times$ )

$\mathrm{K}=$ kontrol; $\mathrm{P}=$ perlakuan; st $=$ sternum; $\mathrm{a}=$ sternebra asimetris; $\mathrm{b}=$ sternebra bercabang dua; $\mathrm{c}=$ sternebra ke-5 anginesis; $d=$ sternebra ke-2, 3, 4, 5 anginesis dan rangkap

Kelainan hidrosefalus pada fetus mencit banyak terjadi pada pemberian nikotin dosis $3 \mathrm{mg} / \mathrm{kg}$ BB pada induk dengan UK 8 dan 10 hari. Sedangkan tidak ditemukan pada UK 12 hari. Hasil tersebut dapat dilihat pada Tabel 6 dan Gambar 6.

Tabel 6. Persentase kejadian kelainan hidrosefalus pada fetus setelah pemberian berbagai dosis nikotin pada induk dengan umur kebuntingan tertentu

\begin{tabular}{|c|c|c|c|c|c|}
\hline \multirow{2}{*}{$\begin{array}{c}\text { Umur } \\
\text { Kebuntingan } \\
\text { (hari) }\end{array}$} & \multicolumn{4}{|c|}{ Dosis Nikotin (mg/kg BB) } & \multirow[b]{2}{*}{ Total } \\
\hline & 0 & 3 & 6 & 12 & \\
\hline 8 & 0.00 & 52.78 & 66.67 & 50.00 & $42.36^{k}$ \\
\hline 10 & 0.00 & 25.00 & 0.00 & 0.00 & $6.25^{\ln }$ \\
\hline 12 & 0.00 & 0.00 & 0.00 & 0.00 & $0.00 \mathrm{mn}$ \\
\hline Total & $0.00^{a}$ & $25.93^{b c}$ & $22.22 b c$ & $16.67^{a b}$ & 16.20 \\
\hline
\end{tabular}

Keterangan: superskrip huruf yang sama tidak berbeda nyata $(p>0,05)$
Dari hasil uji BNT, terlihat bahwa UK 8 hari dengan UK 10 hari maupun UK 12 hari, menunjukkan adanya perbedaan yang nyata terhadap persentase kejadian kelainan hidrosefalus fetus pada $\alpha=0,05$. Sedangkan UK 10 hari dengan UK 12 hari tidak menunjukkan perbedaan yang nyata terhadap persentase kejadian kelainan hidrosefalus fetus pada $\alpha=0,05$.

Pemberian nikotin 3 dan 6 mg/kg BB dibandingkan dengan kontrol, menunjukkan adanya perbedaan yang nyata terhadap persentase kejadian kelainan hidrosefalus fetus pada $\alpha=0,05$. Sedangkan dosis nikotin $12 \mathrm{mg} / \mathrm{kg}$ BB dibandingkan dengan kontrol dan dosis $3 \mathrm{mg} / \mathrm{kg}$ BB dibandingkan dengan 6 dan $12 \mathrm{mg} / \mathrm{kg} \mathrm{BB}$, maupun dosis $6 \mathrm{mg} / \mathrm{kg}$ BB dibandingkan dengan $12 \mathrm{mg} / \mathrm{kg}$ BB tidak menunjukkan adanya perbedaan yang nyata terhadap persentase kejadian kelainan hidrosefalus fetus pada $\alpha=0,05$. 
Pada penelitian ini kelainan hidrosefalus paling tinggi kejadiannya adalah pada perlakuan UK 8 hari (50-66,66\%). Pada UK tersebut otak masih terus berkembang sehingga kelainan hidrosefalus tersebut diduga disebabkan oleh beberapa hal di antaranya adalah penyumbatan aquaductus Sylvii, ketidakseimbangan antara sekresi cerebrospinal fluid dan absorpsi dari choroid plexus di dalam rongga ventrikel (Aolad et al., 2000).

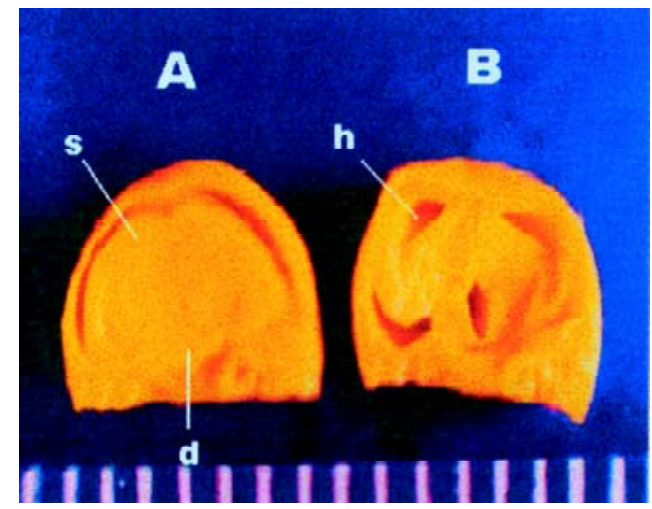

Gambar 6. Hidrosefalus pada Fetus Mencit (perbesaran $10 \times$ ) $\mathrm{A}=$ Kontrol; $\mathrm{B}=$ Perlakuan; $\mathrm{S}=$ serebrum $\mathrm{h}=$ hidrosefalus $\mathrm{d}=$ diensephalon

Persentase kelainan ginjal ektopik (letak ginjal tidak sejajar) banyak terjadi pada UK 8 hari dengan dosis nikotin $6 \mathrm{mg} / \mathrm{kg}$ BB. Pada dosis $12 \mathrm{mg} / \mathrm{kg}$ BB dengan UK 12 hari tidak teramati sebab fetus mengalami retardasi. Hasil tersebut dapat dilihat pada Tabel 7 dan Gambar 7.

Dari hasil uji BNT terlihat bahwa UK 8 hari dengan UK 12 hari dan UK 10 hari dengan UK 12 hari menunjukkan perbedaan yang nyata terhadap persentase kejadian kelainan ginjal ektopik fetus pada $\alpha=0,05$. Sedangkan UK 8 hari dengan UK 10 hari tidak menunjukkan perbedaan yang nyata terhadap persentase kejadian kelainan ginjal ektopik fetus pada $\alpha=0,05$.

Pemberian nikotin dosis 3 dan $6 \mathrm{mg} / \mathrm{kg} \mathrm{BB}$, menunjukkan adanya perbedaan yang nyata dengan kontrolnya terhadap persentase kejadian kelainan ginjal ektopik fetus pada $\alpha=0,05$. Sedangkan nikotin dosis $12 \mathrm{mg} / \mathrm{kg}$ BB dibandingkan dengan kontrol, dan $3 \mathrm{mg} / \mathrm{kg}$ BB dibandingkan dengan $12 \mathrm{mg} / \mathrm{kg}$ BB dan $6 \mathrm{mg} / \mathrm{kg}$ BB dibandingkan dengan $12 \mathrm{mg} / \mathrm{kg}$ BB tidak menunjukkan perbedaan yang nyata terhadap persentase kejadian kelainan ginjal ektopik fetus pada $\alpha=0,05$.
Tabel 7. Persentase kejadian ginjal ektopik pada fetus setelah pemberian berbagai dosis nikotin ikotin pada Induk dengan waktu kebuntingan tertentu

\begin{tabular}{|c|c|c|c|c|c|}
\hline \multirow{2}{*}{$\begin{array}{c}\text { Umur } \\
\text { Kebuntingan } \\
\text { (hari) }\end{array}$} & \multicolumn{4}{|c|}{ Dosis Nikotin (mg/kg BB) } & \multirow[b]{2}{*}{ Total } \\
\hline & 0 & 3 & 6 & 12 & \\
\hline 8 & 0.00 & 30.50 & 33.17 & 11.10 & $18.69^{k}$ \\
\hline 10 & 0.00 & 22.50 & 26.33 & 18.69 & 16.19 \\
\hline 12 & 0.00 & 6.67 & 5.50 & 0.00 & 1.04 \\
\hline Total & $0.00^{a}$ & $19.89^{b c}$ & $21.67^{b c}$ & $9.81^{\mathrm{ac}}$ & 12.84 \\
\hline
\end{tabular}

Keterangan: superskrip huruf yang sama tidak berbeda nyata $(p>0,05)$

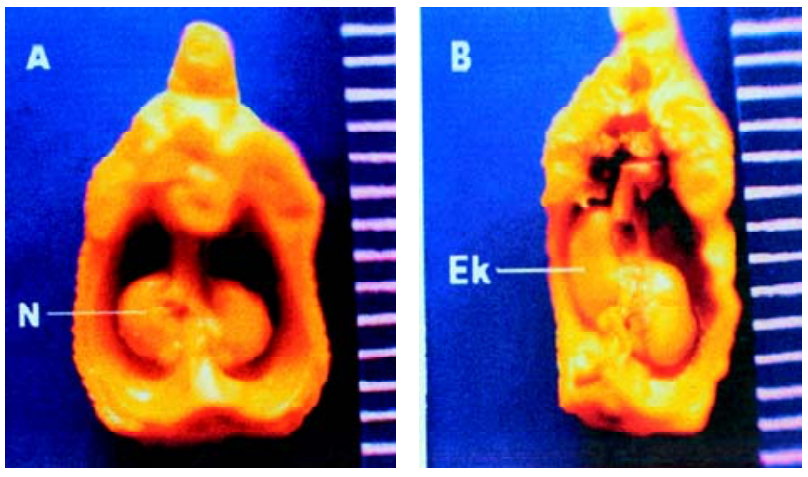

Gambar 7. Ginjal Fetus Mencit (perbesaran $10 \times$ )

A = Ginjal normal; $B=$ Ginjal ektopik; $N=$ normal; Ek = ektopik

\section{PEMBAHASAN}

Dari hasil penelitian ini nikotin mampu menghambat proses osifikasi, sehingga menyebabkan kelambatan penulangan yang terlihat pada kelambatan proses penulangan pada tulang supraoksipital, vertebra di bagian sakro-caudal dan penulangan pada komponen tulang jari baik pada anggota depan maupun belakang namun tidak menunjukkan adanya adanya kelainan rangka.

Tulang supraoksipital fetus mencit mulai mengalami penulangan pada umur 16 hari (Rugh, 1968). Penulangan tulang supraoksipital termasuk dalam jenis penulangan endokodral dengan dua pusat penulangan (Darmanto, 1993). Kelambatan penulangan tulang supraoksipital pada penelitian ini diperlihatkan dengan bentuk tulang supraoksipital dengan penyatuan dua pusat penulangan belum sempurna dan ukuran lebih kecil dari normal serta belum terjadi penulangan tulang supraoksipital. Persentase kejadian ini menunjukkan adanya dose-response relationship. 
Menurut Rugh (1968) vertebra kaudalis mulai menulang pada UK 17 hari dan pola pembentukan calon vertebra terjadi sebelum UK 17 hari, yaitu mulai UK 9 sampai 12 hari (Darmanto, 1998). Kelainan pada sternebra juga terjadi berupa kelambatan proses penulangan maupun asimetris vertebra. Tulang sternebra merupakan hasil fusi dari dua tulang dari sisi kanan dan kiri yang akan membentuk sternebra secara utuh (Taylor, 1986). Tampaknya nikotin menyebabkan ketidaksempurnaan penyatuan penulangan tersebut.

Kelainan internal yang teramati pada penelitian adalah hidrosefalus dan ektopik ginjal. Pada masa embrio ginjal semula terletak di daerah panggul, kemudian bergeser ke kedudukan lebih ke kranial di rongga perut. Dalam perjalanan naik ke rongga perut ini, ginjal dialiri darah oleh pembuluh nadi yang berasal dari aorta yang letaknya semakin meninggi. Selama gerakan ke kranial, ginjal berjalan melewati sudut percabangan yang dibentuk oleh arteri umbilikales, tetapi kadang-kadang satu di antaranya gagal melewatinya. Ginjal tersebut tetap berada di dalam panggul di dekat arteri iliaka komunis dan dikenal sebagai ginjal pelvis (Warkany, 1971). Pada penelitian ini diduga nikotin menghambat pasokan darah melalui arteri umbilikalis sehingga perjalanan ginjal ke kranial di rongga perut terhambat.

Dari data hasil penelitian secara umum dapat disimpulkan bahwa nikotin mampu menyebabkan kelambatan proses penulangan khususnya pada tulang supraoksipital, vertebra sakro-kaudalis, komponen tulang digit dan sternum. Selain itu nikotin mampu menyebabkan kelainan pada organ internal mencit khususnya kelainan otak berupa hidrosefalus dan kelainan ginjal ektopik.

\section{KEPUSTAKAAN}

Amitage AK, Dollery CT, George CF, Housen TH, Lewis PJ, and Turner DM, 1975. Absorption and Metabolism of Nicotine from Cigarettes. Brain Medical Journal, 4: 313-316.
Anonim, 2003. Passive Smoking During Pregnancy. http:// members. aol.com/toxicol98/neversmoke/p10e.htm. Akses 2 Maret 2003.

Aniwidyaningsih W, 2003. Bahaya Asap Rokok terhadap Kesehatan Anan. http://members.aol.com/profchm/ davis.html. Akses 16 Maret 2003.

Aolad HMD, Inouye M, Darmanto W, Hayasaka S, and Murata Y, 2000. Hydrocephalus in mice following $X$-irradiation at early gestational stage: Possible due to persistent deceleration of cell proliferation. Journal of Radiation Research; 41: 213-226.

Benowitz NL, 1980. Pharmacologic Aspects of Cigarette Smoking and Nicotine Addiction. New Engle Journal of Medical. England.

Britton J, Jarvis M, McNeil A, Bates C, Cuthbertson L, and Godfrey C, 2001. Penanganan Adiksi Nikotin. http:// members.aol.com/profchm/davis.html. Akses 16 Maret 2003.

Comroe JH, 1960. The Pharmacologic Action of Nicotin. Ann NY acod., New York.

Darmanto W, 1993. Pengaruh Asam Metoksiasetat terhadap Perkembangan Pralahir Mencit (Mus musculus) Albino Galur A/J. Tesis. Institut Teknologi Bandung. Bandung.

Darmanto W. 1998. Effects of 2-methoxyethanol on the somite formation and skeletal malformation of mice. Proceedings of the $7^{\text {th }}$ Scientific meeting (TI-VI) Indonesian Students Association in Japan, Hiroshima p. 19-22.

Elliot A and Unger TJ, 2003. The Developmental Effect of Nicotine Chik Embryos.http://www.swarthmore.edu/ NatSci/sgilberl/DB_lab/ Student/Nicotine/Nicotine.html. Akses 6 Maret 2003.

Goodman and Gilmans, 1990. The Pharmacological Basic of Therapeutics, $8^{\text {th }}$ ed. New York.

Rugh R, 1968. The Mouse; Its Reproduction and Development. Burgess Publishing Company, Mineapolis, pp. 237-238.

Sudjana, 1984. Metode Statistik. Ed ke-3 Tarsito Bandung, hlm 231-234.

Taylor P, 1986. Practical Teratology. Academic Press, London. Warkany J. 1971. Congenital MalformationsNotes and Comments. Year Book Medical Publishers. Inc., Chicago. p. 1053

Werler MM, Pober BR and Holmes LB, 1985. Smoking and Pregnancy. Teratology 32 : 437-481.

Reviewer: Prof. Dr. Sutiman B Sumitro 